Gadjah Mada International Journal of Business

January 2003, Vol. 5, No. 1, pp. $33-56$

\title{
FACTORS AFFECTING EFFECTIVENESS OF CHANGE INITIATIVES Evidence from Malaysian Firms
}

\author{
Mohd Nazari Ismail \\ Shreen Ahmad
}

This paper investigates various system models and change guidelines that deal with the dynamics of successful change. It seeks to find out whether Malaysian organizations which have achieved successful change outcomes would have also managed the change process in accordance to the general guidelines derived from the literature on effective management of change.

Primary data for this study was obtained by conducting a mailed questionnaire survey among executives and managers of seventeen Malaysian organizations. The main method of analysis is by looking at the correlation between an organization's scores on the relevant items in the change process scales and the organization's perceived effectiveness of change, as measured by the organization's change effectiveness scores.

The general finding confirms and reinforces the literature on effective change management. It was found that organizations that were perceived by staff to have achieved successful change outcomes, were also perceived to have managed the change processes well in accordance to general principles derived from research on organizational change.

Keywords: leadership style; managing change; management support; organization vision; successful change outcomes 


\section{Introduction}

Change is one of the most important elements of successful business management today. To remain competitive in increasingly aggressive markets, organizations (and individuals in them) have to adopt a positive attitude towards change, as ignoring or trivializing a change trend can be costly. Organizational change therefore, is a reality of the modern world. No matter how changes are defined, the challenge to the organization is inevitable: balancing the demands and expectations among stakeholders, including employees, management, shareholders, and customers. Without balance, an organization risks an anxious workforce that may yield diminishing productivity.

Research shows that a significant number (nearly two thirds) of all major changes in organizations fail (Maurer 1996). Failed change initiatives represent a tremendous cost to organizations in terms of money, resources and time. Failed change initiatives also take a human toll. Employees are left feeling discouraged, distrustful, and reluctant to participate in the next round of failures (Maurer 1996).

\section{Objectives of the Study}

The main purpose of this study is to test various system models and change guidelines that deal with the dynamics of successful change. It is hypothesized that those organizations, which were assessed by respondents to have achieved successful change outcomes, would have also managed the change process in accordance to the general guidelines derived from the literature on the effective management of change. Another purpose of this study is to determine whether the general guidelines on managing change are applicable to Malaysian organizations.

\section{Literature Review}

In his well-known model of change, Kurt Lewin (1958) presented a fundamental description of change and described the change process of a system as a series of transitions between three different phases: unfreezing -transition- refreezing. According to Lewin's force field analysis, managers create planned change by altering the restraining and driving forces. A careful analysis is needed to determine how the restraining forces can be reduced and/or how the driving forces can be strengthened. Lewin's force field analysis has been a popular model for analyzing change programs and predicting the effects of future changes.

A range of writers has provided guidelines on the principles and practices underlying the successful management of organizational change. Nadler (1981, 1989) discussed various types of change. He distinguished between changes that are incremental and which focus only on specific subsystems of the organization, and changes, which are strategic. The latter types of change are "frame bending" in that frequently involve breaking out of a current pattern of "congruence" and helping an organization to develop a completely new configuration.

Dunphy and Stace (1990) provided a situational model of organizational change. To define their "scale of change" dimension, four types of changes were elaborated:fine-tuning, incremental adjustment, modular transformation, corporate transformation. Cummings and Worley (1997) also discussed the magnitude of change. According to them, planned change efforts can be characterized as falling along a continuum, ranging from incremental changes that involve fine-tuning the organization to quantum changes that entail fundamentally altering how it operates. 
Ismail \& Ahmad_Factors Affecting Effectiveness of Change Initiatives

Many writers stress the importance of the development and communication of a vision by leaders as part of the change process (Kanter 1992; Kotter 1995; Morris and Raben 1995). According to Kotter (1995), in every successful transformation effort, the guiding coalition develops a picture of the future that is relatively easy to communicate and appeals to stakeholders. Generally, the vision describes the desired future towards which change is directed (Cummings and Worley 1997). Without a sensible vision, a transformation effort can easily dissolve into a list of confusing and incompatible projects that can take the organization in the wrong direction or nowhere at all (Burke 1994). In less successful cases, management had a sense of direction, but it was too complicated or blurry to be useful (Kotter 1995). According to Kotter, "If you cannot communicate the vision to someone in five minutes or less and get a reaction that signifies both understanding and interest, you are not yet done with this phase of the transformation process." Vaill (1993) emphasized the fact that vision is indispensable: "It is the basis on which the organization acquires and maintains personal meaning for all those associated with it." Nadler (1981) similarly pointed to the need for change to design a future state. Typically, this involves a determination of desired output, the development of strategy to achieve that output, and the design of task, individual, formal organization, and informal organization component configuration needed to execute that strategy.

Nadler (1989) further suggested that employees seem to be capable of simultaneously integrating only a limited number of themes for change. Without a sound vision, change projects will not add up in a meaningful way. According to him, in many failed change efforts, there are often plenty of plans, and direction and programs, but there is no vision.

A necessary condition for successful implementation of organizational change is the perceived, active and symbolic support and commitment by the leaders of the organization (Mansis Index of Organizational Change 2000). Any leadership action in an organization domain has potential symbolic value (Zaleznik 1992). Bartlett and Ghoshal (1994), in their longitudinal study of numerous organizations, also see leadership as a crucial matter in managing change. Leaders have a difficult task of promoting change when employees are seeking a sense of stability (Moran and Brightman 1996). Leaders must be prepared to "walk the talk" (Abraham et al. 1996). They must be prepared to act in ways that are congruent with the message contained in the vision. Covey (1997) indicated that the "task of leaders is to create a culture that values integrity and empowerment. Without that culture, you may have formal leaders but you won't have true leadership."

Stace and Dunphy (1994) indicate that leadership at the top is not enough. Success depends on building a broader base of support with other individuals who first act as followers, then as helpers and finally as co-owners of the change. They believe that the workforce should be involved in the setting of major organizational goals for change as well as in their implementations.

Nadler (1981) pointed to participation as one of the key action steps to motivate change. Reichers et al. (1997) found that over two-thirds of the respondents in their study would like a high degree of participation in decision-making. 
Gilliam's (1986) found that employees often direct their energy into resistance due to lack of knowledge that would allow them to channel their energy into support. According to Abraham et al. (1999), largescale change requires the allocation of considerable resources in support of the change. Financial and human resources must be allocated to plan, monitor and implement the change. Nadler (1981) emphasized the necessity for allocating such resources to the change processes.

The empowerment of subordinates as well as recognition and reward for good work, have been clearly recognized as effective organizational practices (Abraham et al. 1999). Block (1987), Sathe (1985) and Weisbord (1989) have similarly emphasized the importance of recognition and reward in motivating work performance.

Nadler (1981) pointed out that "rewards such as bonuses, pay systems, promotions, recognition, job assignment, and status symbols all need to be carefully examined during major organizational changes and restructured to support the direction of the transition." The Mansis Index of Organizational Change (2000) reinforced this fact by explaining that expectation of reward and recognition are the measure of employee belief and trust in management and the organization wishes to keep promises and to recognize good employee performance. Without this expectation, employees resist the risk associated with organizational change.

Ulrich and Lake (1991) maintained that there should be less emphasis on punitive practices and more on rewards as a positive force aiming at shaping the desired behaviours. Spritzer (1996) provided a number of reasons why organizational rewards fail to have the desired motivational impact. Among these are an exces- sive dependency on monetary rewards, lack of recognition value of the rewards, and rewarding the wrong performances. Kohn (1993), an opponent of rewards and incentive plans, pointed out that rewards succeed at securing only one thing, that is temporary compliance. According to him, when it comes to producing lasting change in attitudes and behaviours, rewards, like punishment are strikingly ineffective.

Some writers emphasize the importance of special structures needed to effectively manage the change process. According to Nadler (1981), these "parallel" structures are developed outside the normal structure to enable the management and monitoring of change processes as a whole, without putting a strain on regular organizational arrangements. Morris and Raben (1995) supported Nadler's point by suggesting that there was a need for a particular "transition manager" driving the change, with a network of "transition coordinators" to form such a parallel structure. This parallel structure can include special task forces, cross-functional teams, pilot projects and experimental units.

Beckhard and Harris (1987) recommended the creation of a transition management team (TMT) with resources and influences to integrate and manage the change process. Duck (1993) similarly draws attention to transition management teams in managing organizational change.

Many writers explained how clear, honest and frequent communication is important for organizational change to be successful (Covin \& Kilmann 1990; Bronson 1991; Covin 1993; Young \& Post 1993). Sharing information and empathizing with employee concerns can help minimize speculation and anxiety. Effective communication can take away at least part of the feeling of uncertainty and lack of information about the change, reducing 
Ismail \& Ahmad_Factors Affecting Effectiveness of Change Initiatives

speculation and unfounded fears. Communication needs to be managed so that at any point in the transition, confusion can be avoided through coherent, accurate and honest messages using a variety of media, which is expected to have broad coverage and frequent impact (Kanter 1992). Communication further occurs through evidence of action matching rhetoric and the use of symbols and language to create energy (Morris and Raben 1995).

Some writers highlight the importance of having many points of leverage, which have to be simultaneously used to bring about successful organizational change. Nader (1981) pointed out the need for the infrastructure of the organization to be adjusted in order to be consistent with, and in support of the change. Others focused on planning processes, information systems, rewards and incentives, standards and measures of performance, budgeting and resource allocations which must not be allowed to lag behind the change (Abraham et al. 1997).

\section{Research Hypotheses}

The followings are hypotheses to be tested in this study:

$H_{1}$ : Successful change outcomes would be associated with action by senior management to develop, justify and communicate an organization's vision with a limited number of clear and consistent themes for change.

$\mathrm{H}_{2}$ : Successful change outcomes would most likely be associated with cohesive actions from the CEO, board and seniormanagement team increating a sense of urgency, sharing and championing a common vision and modelling appropriate change behaviours to manage alignment behind the vision.
$H_{3}$ : Successful change outcomes would most likely be associated with a leadership style, which emphasized involvement, participation and empowerment.

$H_{4}$ : Successful change outcomes would be accompanied by the provision of adequate financial, human, training resources and management support.

$H_{5}$ : Successful change outcomes would have been specifically associated with a variety of rewards with the power to motivate appropriate change behaviours - e.g. personal satisfaction, challenge, identification with and ownership of the change, identification with influential managers, financial rewards, team pressure, and so forth.

$H_{5 a}$ : Motivational strategies that emphasized punitive action would not be associated with successful change outcomes.

$H_{6}$ : Successful change outcomes would be accompanied by specific structural arrangements to manage the change.

$H_{7}$ : Successful change outcomes would most likely be associated with communication strategies that emphasized direct communication and "proof" by managers of commitment to the change process as well as a variety of media emphasizing written or symbolic communication.

$H_{8}$ : Successful change outcomes would most likely be associated with all the above dimensions at once. In other words, $H_{1}$ to $H_{7}$ would apply together rather than selectively.

The last hypotheses basically postulates the integrated nature of the "universalistic principles" associated with Hypotheses 1-7. 
Gadjah Mada International Journal of Business, January 2003, Vol. 5, No. 1

\section{Research Methodology}

\section{Data}

Primary data for this study was obtained by conducting a survey. Sampling technique is a combination of convenience, quota and purposive sampling. A total of 238 questionnaires were distributed to 17 locally incorporated organizations confined within the Federal Territory Kuala Lumpur and Selangor, Malaysia. A total of 193 responses were obtained, giving an average of 11.4 responses per organization and an overall response rate of 81.1 percent. The detail of the organizations in term of industry is presented in Table 1.

The survey instrument was a tenpage questionnaire using 5-point Likerttype scale of $1-5$, with $1=$ Strongly Disagree, 2= Disagree, 3= Neutral, 4= Agree, and 5 $=$ Strongly Agree. The questionnaire is adapted from Abraham et al. (1999).

\section{Formation of Organization- Level Variables and Effectiveness Composite Measures}

The statistical analyses relevant to the examination of the research hypotheses require analyses at the organization level, i.e. with the organization as the unit of analysis. Thus, the data from the 193 returned questionnaires were initially coded into a data matrix with each respondent (or questionnaire) as a unit of analysis. From this, a data matrix with each organization as the unit of analysis was formed by aggregating the responses from each of the organizations on each of the items on the questionnaire. For questionnaire items with a rating scale response format (all items in Sections I, J, K, L, M, $\mathrm{N}, \mathrm{O}$ ), an organization's score on a particular item was calculated as the average

Table 1. Organizations Included in the Study

\begin{tabular}{|c|c|}
\hline Organization & Industry / Core Business \\
\hline 1 & Aviation \& Aerospace / Transport \\
\hline 2 & Banking \& Finance / Commercial Banking \\
\hline 3 & Banking \& Finance / Commercial Banking \\
\hline 4 & Banking \& Finance / Commercial Banking \\
\hline 5 & Oil \& Gas / Petrochemical \\
\hline 6 & Communications \& Multimedia / Telecommunications \\
\hline 7 & Information Technology / Computer Hardware/Software/Solutions \\
\hline 8 & Communications \& Multimedia / Telecommunications \\
\hline 9 & Communications \& Multimedia / Telecommunications \\
\hline 10 & Infrastructure / Construction \& Power Generation \\
\hline 11 & Investment (Statutory Body) \\
\hline 12 & Taxation (Statutory Body) \\
\hline 13 & Insurance / Life Insurance \\
\hline 14 & Banking \& Finance / Commercial Banking \\
\hline 15 & Consulting / External Auditing \\
\hline 16 & Insurance / Life Insurance \\
\hline 17 & Education / Tertiary Education \\
\hline
\end{tabular}


rating given for that item by all the respondents from that organization.

Questionnaire items in Section Hyield categorical responses and therefore, the formation of organizational variables by the calculation of mean scores would be inappropriate. For this section, organization level variables were generated by defining a new variable for each of the four response options. The score on each of these variables was calculated as the proportion of respondents within each organization that marked each of the four categories. Therefore, for Section $\mathrm{H}$, four new organizational level variables were formed (H1, H2, H3 and H4) corresponding to each of the response categories 1 to 4 with an organization's score on (say) variable $\mathrm{H} 1$ being the proportion of respondents from that organization that chose option 1 for Section $\mathrm{H}$.
The research hypotheses for this study relate to the relationships between an organization's scores on the relevant items in the change process scales and the organization's perceived effectiveness of change, as measured by the organization's scores on the final ten items in the questionnaire (Section O, Items 1-10). Inspections of the correlations (across the 17 organizations) among these ten effectiveness items showed them to be relatively strong and positively associated, which suggested that these items might be validly combined to form a composite effectiveness score for each organization. This was confirmed by the high Cronbach Alpha reliability estimate of 0.98 for an effectiveness measure calculated as the average of an organization's scores on items O1 - O10 (Reliability Analysis for Effectiveness measure shown in Table 2). The

Table 2. Reliability of Composite Effectiveness Scale

\begin{tabular}{|c|c|c|}
\hline Item & The change resulted in: & $\begin{array}{l}\text { Alpha If } \\
\text { Item } \\
\text { Deleted }\end{array}$ \\
\hline$\overline{\text { Effectiveness } 1}$ & Improved products or services & .9857 \\
\hline Effectiveness 2 & Measurably higher productivity & .9866 \\
\hline Effectiveness 3 & Improved services to customers and clients & .9864 \\
\hline Effectiveness 4 & $\begin{array}{l}\text { Measured improvements in goal-oriented } \\
\text { criteria, such as revenues, growth, customer } \\
\text { satisfaction, or other such criteria }\end{array}$ & .9870 \\
\hline Effectiveness 5 & Improved efficiency & .9873 \\
\hline Effectiveness 6 & Greater ability to compete in the marketplace & .9873 \\
\hline Effectiveness 7 & An overriding culture of quality and excellence & .9856 \\
\hline Effectiveness 8 & $\begin{array}{l}\text { A sense of awareness, belonging and feeling } \\
\text { part of the team/organization }\end{array}$ & .9870 \\
\hline Effectiveness 9 & $\begin{array}{l}\text { A greater sense of cohesion and integration in } \\
\text { the organization }\end{array}$ & .9870 \\
\hline Effectiveness 10 & Greater long-term health of the organization & .9872 \\
\hline
\end{tabular}

Alpha $=0.9880$ 
Cronbach alpha reliability estimate was slightly reduced with the removal of any of the ten items from the composite measure indicating that all ten items were important in the scale. The final ten items were averaged to form a composite effectiveness score for each organization, which is labeled effectiveness. The main method of analysis is by looking at the correlation between an organization's scores on the relevant items in the change process scales and the organization's perceived effectiveness of change, as measured by the organization's change effectiveness scores.

\section{Research Results}

The detailed results of this study are presented in Appendix 1.

\section{Hypothesis 1}

There is clear support for Hypothesis 1 relating to visions and supporting plans. The highest correlation with effectiveness are with the existence and extent to which there was a plan detailing the various steps of the change (Item I8, r = 0.797) and a clear picture of how the organization will look like in the future (Item I11, r = 0.776). High correlations are also associated with a clear indication of how the change would impact upon your job (Item I9, $\mathrm{r}=0.710$ ) and an explanation of the advantages to key internal groups (Item I4, $\mathrm{r}=0.709$ ).

All correlations were significant at the 0.01 levels, except for items $I 1, I 2$ and 110 which were not significantly correlated with effectiveness. The results for the three items may indicate that given the fact that the magnitude of change was mostly small to medium scale, and not organization-wide (refer section 3.3.1), the limited number of themes and directions were not particularly applicable in this study (Items I1 and I2) and did not entail major changes in the organizations' core values and beliefs (Item I10).

\section{Hypothesis 2}

With the exception of Item $J 1$, all items were correlated with effectiveness at the 0.01 and 0.05 levels. Item $J I$ was not significantly correlated possibly due to the fact that employees did not need top management to remind them that old ways were unsatisfactory.

The highest correlation with effectiveness was for Item $J 9$ with $r=0.886$. This clearly indicates that for change to be effective, it is critical for top management to "walk-the-talk" by leading the change with every word and action. This fact is further reinforced by the high correlation with Item $J 8(\mathrm{r}=0.803)$, in the importance of leaders modeling appropriate behaviours.

The correlations with items $J 2, J 5, J 6$ and $J 10(\mathrm{r}=0.722,0.580,0.779$ and 0.782 , respectively) offer clear support for $\mathrm{Hy}$ pothesis 2 relating to the importance of cohesive action in leading the change from the top and championing a common vision.

The second highest correlation was with item $J 11(\mathrm{r}=0.856)$. The explanation may lie in the characteristics of most organizations where the power to implement changes successfully more often than not lies with the employees. Since the critical mass can either 'make or break' the organizational change effort, effective support building must therefore involve the employees rather than those perceived to be in positions of power. This is further supported by correlations with items relating to participation (items $\mathrm{J} 12-\mathrm{J} 15$ ), to be explained in the next section. While this is true, it is also important to provide support to those who experience difficulties in adjusting to new ways (item $\mathrm{J} 4, \mathrm{r}=0.816$ ). 
Ismail \& Ahmad_Factors Affecting Effectiveness of Change Initiatives

\section{Hypothesis 3}

There was strong support for this hypothesis, which was generated from the universal prescriptions regarding the importance of participative leadership. High correlations with effectiveness for items $J 12$ - J15 indicates that participation of employees is highly desirable for change to be effective. Items $J 14$ and $J 15$ had very high correlations with effectiveness $(\mathrm{r}=$ 0.856 and 0.832 respectively).

\section{Hypothesis 4}

With the exception of item $K 2$ (r= 0.774 at the 0.01 level), the other three items (K1, K2 and K4) were significant at the 0.05 level. This indicates that sufficient resources in terms of finances, human resources, training and management support are important to ensure effective change. This may apparently be so in the cases of moderate to large-scale change such as modular and corporate transformation programmes where substantial resources (financial and human) are important to support the change and to help employees adjust to new ways of doing things (training and management support).

\section{Hypothesis 5}

The motivation and reward items can be broadly divided into three distinct categories. First, those rewards that were intrinsic in nature to the individual respondents such as personal satisfaction, challenge and development of new skills and competencies, confidence, internalization and personal ownership of the change (items L1, L2, L7, L9 and L10). All correlations in this category were high at the 0.01 significance level except item L7 which was significant at the 0.05 level). The highest three correlations in the moti- vation and rewards scale were in this category, namely item L9 (staff internalization of the change process, $r=0.931$ ); item L1 (personal satisfaction, $\mathrm{r}=0.880$ ) and item $L 10$ (personal ownership, $\mathrm{r}=0.825$ ). Item $L 2$ (challenge) had a correlation of 0.774 . Item $L 7$, which is essentially the opposite of internalizing the change had a negative correlation $(\mathrm{r}=-0.511)$.

The second category in the motivation and rewards scale related to those items that were extrinsic in nature to the individual such as money (item L4), team pressure (item L5), identification with managers who modeled appropriate behaviors (item L8) and visible recognition for actively supporting the change (item L11). Correlations with effectiveness were significant for items $L 4(\mathrm{r}=0.778)$ and $L 8$ $(\mathrm{r}=0.668)$ at the 0.01 level. For items $L 5$ and $L 11$, correlations were significant at the 0.05 level ( $r=0.493$ and 0.594 respectively).

The third category related to negative or punitive rewards applied to overcome resistance to change (Items L3, L6 and L12). All three correlations were not statistically significant indicating that punitive measures did not have an effect the effectiveness of change efforts.

The study results attest to the relative importance of intrinsic rewards (Spritzer 1996). They also support Ulrich and Lake's (1991) proposition that there should be less emphasis on punitive practices and more on rewards that have the power to motivate and shape desirable behaviours in the organization. Therefore, the results revealed that there was strong support for both Hypotheses 5 and $5 a$, in that a variety of rewards in the form of positive reinforcements are important for motivating change and punitive action would not be associated with positive change outcomes. 


\section{Hypothesis 6}

Items $M 1-M 9$ outlined the structural arrangements that are associated with successful change efforts from the general literature on change management. Items $M 1$ and $M 2$ specifically relate to the hierarchical arrangements for managing the change effort. However, correlations with effectiveness for these two items were not significant suggesting that formal hierarchical arrangements were not necessary for successful change outcomes.

The most significant correlations were for items $M 9, M 7, M 6$ and $M 8$ (r=0.796, $0.725,0.673$ and 0.629 respectively). These correlations which are significant at the 0.01 level, indicate that change structures that promote and enhance effective twoway communication are essential for effective change. This sort of change structure incorporates clear and flexible communication (item M9), effective networking among organizational members (item M7), effective feedback mechanisms (item M6) and a special communication network distinct from the organizational hierarchy (item M8).

\section{Hypothesis 7}

The questionnaire items in Section $\mathrm{N}$ examined the extent of use (Items N1-N6) and perceived effectiveness (Items N7N12) of a variety of communication strategies in supporting and facilitating the change.

With respect to the extent of use of communication strategies, items $\mathrm{N} 2, \mathrm{~N} 3$ and $N 4$ were not significant. The most significant items are $N 6(\mathrm{r}=0.910)$, which is related to managers visibly supporting the change through word, and item N5 ( $\mathrm{r}=$ 0.806 ), which is related to recognition and reward to those who support the change. Item $N 1$ (regular messages on the bulletin board and other public forums) was significant at the 0.05 level $(r=0.558)$.
With respect to the perceived effectiveness of use, all items were significantly correlated with effectiveness. The first three items had relatively low correlations (items N7, N8 and N9 with $\mathrm{r}=0.600$, 0.660 and 0.593 respectively). The highest three correlations were items $N 11, N 12$, and $N 10(\mathrm{r}=0.803,0.745$ and 0.721 respectively), which are significant at the 0.01 level.

These results imply that employees generally were not taken in by words, symbols or the number of communication channels or frequency of communication, but rather the quality and effectiveness of the communication. The respondents seemed to require "proof" of commitment to and genuine belief of the change effort and face-to-face communication via meetings. Evidently, employees were of the view that recognition and reward to those who support the change is important for its success (item N6 and N12 with $\mathrm{r}=0.910$ and 0.745 , respectively).

\section{Hypothesis 8}

This hypothesis is related to the effective use of "multiple leverage points" in managing the change effort and integration of the universalistic principles associated with Hypotheses 1-7. It is important that these change processes be aligned with and supportive of one another to create a common objective and to result in a successful change outcome. These change processes would work together 'in harmony' rather than work selectively to produce effective change.

The results indicated strong support for these universalistic principles and propositions for managing the change process in order to produce a positive and effective outcome. It is evident from the results (Hypothesis 1-7) that all the change processes would need to be managed well for the change to be successful, as this 
Ismail \& Ahmad_Factors Affecting Effectiveness of Change Initiatives

would not be possible if each process worked in isolation.

\section{Change Strategy and Perceived Effectiveness}

It is also of interest to examine the correlations with effectiveness for the variables relating to change strategy (items $\mathrm{H} 1-\mathrm{H} 4)$.

Items $\mathrm{HI}-\mathrm{H} 4$ formed a scale reflecting the magnitude or degree of change, with fine-tuning representing minimal change and corporate transformation representing radical and large-scale change. The results showed that there was no significant correlation between items in the change strategy scale and effectiveness. This clearly implies that the perceived effectiveness of change was not related to the degree of change.

This finding is not surprising since the magnitude or degree of change does not have a bearing on its outcome. This shows that large-scale and complex change could be handled well while small-scale change may be managed poorly (or vice versa).

\section{Multiple Regression}

Regression analysis was also used. For this purpose, composite scores for each variable in the questionnaire (also indicated in the hypotheses) were formed by aggregating the responses from each respondent on all items in each variable. The linear model is as follows:

$$
\begin{aligned}
\mathrm{Y}= & \alpha+\beta_{1} \mathrm{X}_{1}+\beta_{2} \mathrm{X}_{2}+\beta_{3} \mathrm{X}_{3}+\beta_{4} \mathrm{X}_{4}+ \\
& \beta_{5} \mathrm{X}_{5}+\beta_{6} \mathrm{X}_{6}+\beta_{7} \mathrm{X}_{7}+\beta_{8} \mathrm{X}_{8}+\varepsilon
\end{aligned}
$$

Table 3. All Variable Regression -

\begin{tabular}{|c|c|c|}
\hline $\mathbf{R}$ & R-Square & $\begin{array}{l}\text { Adjusted } \\
\text { R-Square }\end{array}$ \\
\hline 0.807 & 0.651 & 0.633 \\
\hline
\end{tabular}
Model Summary

\begin{tabular}{|c|c|c|c|c|c|}
\hline \multirow[t]{2}{*}{ Model } & \multicolumn{2}{|c|}{$\begin{array}{l}\text { Unstandardized } \\
\text { Coefficients }\end{array}$} & \multirow{2}{*}{$\begin{array}{c}\begin{array}{c}\text { Standardized } \\
\text { Coefficients }\end{array} \\
\text { Beta }\end{array}$} & \multirow[t]{2}{*}{$\mathbf{t}$} & \multirow[t]{2}{*}{ Sig } \\
\hline & Beta & $\overline{\text { Std. Error }}$ & & & \\
\hline$\alpha$ (Constant) & -2.700 & 2.836 & -.952 & & .342 \\
\hline Vision & .150 & .082 & .126 & 1.832 & .069 \\
\hline Leadership & .188 & .090 & .169 & 2.101 & .037 \\
\hline Participation & .269 & .181 & .110 & 1.486 & .139 \\
\hline Resources & -.115 & .181 & -.044 & -.636 & .525 \\
\hline Positive rewards & .373 & .105 & .237 & 3.569 & .000 \\
\hline Punitive measures & -.651 & .251 & -.126 & -2.590 & .010 \\
\hline Structure & .171 & .099 & .127 & 1.727 & .086 \\
\hline Communications & .250 & .070 & .250 & 3.578 & .000 \\
\hline
\end{tabular}

Table 4. All Variable Regression - Coefficients

Dependent variable: Perceived effectiveness 
The dependent variable $(\mathrm{Y})$ is Perceived Effectiveness of Change, whereas the independent variables are Vision $\left(\mathrm{X}_{1}\right)$, Leadership $\left(\mathrm{X}_{2}\right)$, Participation $\left(\mathrm{X}_{3}\right)$, Resources $\left(\mathrm{X}_{4}\right)$, Positive Rewards $\left(\mathrm{X}_{5}\right)$, Punitive Measures $\left(\mathrm{X}_{6}\right)$, Structure $\left(\mathrm{X}_{7}\right)$ and Communication $\left(\mathrm{X}_{8}\right)$. The results of the regression are shown in Table 3 and Table 4.

Perceived effectiveness of change is positively correlated with vision, leadership, participation, positive rewards, structure and communications, while it is negatively correlated with resources and punitive measures.

\section{Discussion of Findings}

The general finding confirms and reinforces the literature on effective change management. In other words, the guidelines on change management are relevant for Malaysian managers.

It was found that organizations that were perceived by staff to have achieved successful change outcomes were also perceived to have managed the change processes well in accordance to general principles derived from research on organizational change. More specifically, such organizations:

- Developed and articulated a clear vision of the future and explained the rationale and advantages of the change and how it would impact upon their jobs. A plan detailing the various steps to achieve that vision was also developed and communicated.

- Created energy to get the change initiated and mobilized commitment through leadership by example through visible, active and public support of the change and modeling appropriate behaviors.
- Continually involved more and more people along the way in order to build momentum until 'critical mass' is achieved. These organizations realized the importance of employee support and trust, and thus invited involvement and participation.

- Provided sufficient and appropriate human, financial, training resources and time and energy in support of the change.

- Provided for positive reinforcements in terms of employee development, enhanced self-esteem and overt rewards and recognition.

- Provided for the explicit design of change management structures that promote and enhance effective twoway communication.

- Provided for effective communications strategies to facilitate the change, particularly symbolic actions by management and recognition and reward for those who support the change.

Those organizations perceived to achieve successful change outcomes had undergone what Ulrich and Lake (1991) called the development of "organizational capability". This study demonstrated that in the case of organizations that achieved successful change outcomes, the dimensions of effective change management applied together rather than selectively or in isolation.

The study showed that the key factor in effective change management was the perceived, active and symbolic support and commitment by the leaders of the organization. Management must be clearly perceived to support the change by the manifestation of their belief and commitment through their behaviors, communication and recognition and rewards. Per- 
Ismail \& Ahmad_Factors Affecting Effectiveness of Change Initiatives

ceived weaknesses or doubts in this commitment frequently destroy the implementation of change efforts, therefore management must be prepared to "walk-thetalk" at all times.

Although other factors such as perception and quality of the change plan, clarity of vision, communications and a change strategy that emphasizes participation and avoids the use of punitive measures were also important, it was management support and commitment which was of paramount importance in achieving successful change. Leaders must be prepared to act in ways that were congruent with organizational vision and values. They must be able to lead by example and model appropriate behaviors.

The study also revealed the need for procedures for directed motivation to ensure that employees are motivated to support the change process. Therefore, when implementing change, it was important to ensure that employee performance related to the change paid off. A critical element of employees' motivation in the study was creating and maintaining individual selfconfidence, self-esteem, growth and developmental needs and opportunities in the organization. In other words, the intrinsic aspects of rewards were most powerful and sustaining forces of motivation in organizations. Organizations must take cognizance of this and foster a conducive environment and inculcate a culture that reinforces positive attitudes and good performance.

Employees' motivation was also determined by the expectation of extrinsic rewards, such as money, team pressure and visible recognition for actively supporting the change. In addition, the study also revealed that punitive measures did nothing to motivate employees' performance and support of the change. It is therefore critical for punitive measures not to be built into the organization's systems and structures. This is mainly due to the fact that any measure with a punitive quality has a tendency to make the recipient feel subservient and damage his or her self-esteem. Other methods such as coaching, training and support should be used to encourage desired behaviors and help adjust to new ways, as revealed in the study.

The research findings supported the use of participation in managing the change process. Participative management techniques generally aim to develop a coalition or network of committed individuals who embrace the change effort and visibly support it. This commitment to the organization's vision and initiatives is based on shared values, and thus translates to an extended commitment to change throughout the organization. Participation is crucial in order to obtain extended buyin for the change to happen and provides management with the ability to manage conflicts inherent in change and engage in appropriate problem solving. Although participation is more often than not the approach to use in managing organizational change, factors such as the unique nature of organizations (e.g. professional, non-profit, etc), the context in which the change is to be implemented, and time factor should be taken into consideration.

Statistically significant correlations were also found between the effectiveness measure and most items in the vision, resources, structure, and communications scales. In so far, as visioning is concerned, the findings of the study lend support to the work of authors such as Kanter (1992), Kotter (1995), Morris and Raben (1995), and Nadler (1998) on vision. In order for change to be successful, top management must develop a clear picture of the future, explain the rationale, precursors and ad- 
vantages, develop a plan detailing the various phases of the change, and explain the prerequisites for change and ways in which the change will impact on employees and all aspects of the organization. The results also clearly support Nadler's (1981) study that mentioned effective change necessitates the allocation of resources in support of the change

The study revealed that while putting in place the structural arrangements were necessary, it was those structures that facilitated effective communications that were crucial for successful change. In addition, the results indicate that the change management structure associated with successful change was somewhat more "diffused" than the somewhat more hierarchical version suggested by Nadler (1981).
Employees were of the view that formal committees, teams, task forces, pilot projects and designated transition managers as not as important in leading up to successful change.

Finally, successful change also required effective communications of the change effort. However, in communicating the change, it was apparent that employees were not convinced by merely receiving regular information through the organization's communication channels or management using symbols to facilitate the change. They required more concrete evidence in terms of managers visibly supporting the change through word and action and receiving recognition and reward in support of the change.

\section{References}

Abraham, M., J. Crawford, and T. Fisher. 1996. Key factors predicting effectiveness of cultural change and improved productivity in implementing total quality management. International Journal of Quality and Reliability Management 16 (2).

Abraham, M., T. Fisher, and J. Crawford. 1997. Quality culture and the management of organizational change. International Journal of Quality and Reliability Management 14 (6).

Abraham, M., D. Griffin, and J. Crawford. 1999. Organisation change and management decision in museums. Management Decision 37 (10): 736-751.

Bartlett, C. A., and S. Ghoshal. 1994. Changing the roles of top management: Beyond strategy to purpose. Harvard Business Review (November-December): 79-88.

Beckhard, R., and R.T. Harris. 1987. Organizational Transitions: Managing Complex Change ( ${ }^{\text {nd }}$ Ed.). Reading. MA: Addisson Wesley.

Block, P. 1987. The Empowered Manager. San Fransisco, CA: Jossey-Bass.

Bronson, L. 1991. Strategic change management. Organization Development Journal 9: 61-67.

Burke, W.W. 1994. Organization Development: A Process of Learning and Changing $\left(2^{\text {nd }}\right.$ Ed.). Reading, MA: Addisson-Wesley. 
Ismail \& Ahmad_Factors Affecting Effectiveness of Change Initiatives

Burke, W. W. and L. D. Goldstein. 1980. Organization development today: A retrospective applied to the present and the future. Trends and Issues in Organization Development: 3-15. San Diego, CA: University Associates.

Covey, S. R. 1997. Continual renewal. Executive Excellence 14 (5): 3-4.

Covin, T. J. 1993. Managing workforces reduction: A survey of employee reactions and implications for management consultants. Organization Development Journal 11: 67-76.

Covin, T. J. and R. H. Kilmann. 1990. Participant perceptions of positive and negative influences on large-scale change. Group and Organization Studies 15: 233-248.

Cummings, T. G. and C. G. Worley. 1997. Organizational Development and Change. Cincinnati, Ohio: South-Western College Publishing.

Duck, J. D. 1993. Managing change: the art of balancing. Harvard Business Review 71 (6): 109-18.

Dunphy, D., and D. Stace. 1990. Under New Management: Australian Organizations in Transition. New York: McGraw Hill.

Gilliam, D. J. 1986. Harnessing the energy from anxiety. Supervisory Management (March), 40-43.

Kanter, R. M. 1992. The challenges of execution: Roles and tasks in the change process. The Challenge of Organizational Change (Ch. 10): 369-394. New York: Free Press.

Kohn, A. 1993. Why incentive plans cannot work. Harvard Business Review (SeptemberOctober): 54-63.

Kotter, J. P. 1995. Leading change: Why transformational efforts fail. Harvard Business Review (March-April): 59-67.

Mansis Index of Organizational Change. 1999. http://www.mansis.com/page221 (Accesses on 6 October 2000)

Maurer, R. 1996. Using resistance to build support for change. Journal for Quality and Participation (June): 56-63.

Moran, J. W., and B. K. Brightman. 1996. Leading organizational change. Journal of Workplace Learning: Employee Counselling Today 12 (2).

Morris, K. F., and C. S. Raben. 1995. The fundamentals of change management. In D. A. Nadler, R. B. Shaw, and A. E. Walton. Discontinuous Change: Leading Organizational Transformation. San Fransisco, CA.

Nadler, D. A. 1981. Managing organizational change: an integrating perspective. The Journal of Applied Behavioural Science 17 (2).

Nadler, D. A. 1989. Organizational frame bending: principles for managing reorientation. The Academy of Management Executive 3 (3): 194-204. 
Nadler, D. A. 1998. Champions of Change: How CEO's and Their Companies are Mastering the Skills of Radical Change. San Fransisco: Jossey-Bass Publishers.

Reichers, A. E., J. P. Wanous, and J. T. Austin. 1997. Understanding and managing cynicism about organizational change. The Academy of Management Executive 11 (1 February).

Sathe, V. 1985. Culture and Related Corporate Realities. Homewood, IL: Irwin.

Spitzer, D. R. 1996. Power rewards: Rewards that really motivate. Management Review 85 (May): 45-50.

Stace, D., and D. Dunphy. 1994. Beyond the Boundaries: Leading and Recreating the Successful Enterprise. New York: McGraw Hill Book Company.

Ulrich, D., and D. Lake. 1991. Organizational Capability: Creating Competitive Advantage. Academy of Management Executive 5 (1).

Vaill, P. B. 1993. Visionary leadership. In R. Alan, J. W. Cohen.The Portable MBA in Management (Ch 2). New York.

Wiesbord, M. 1989. Productive Workplaces. San Fransisco, CA: Jossey-Bass.

Young, M. B., and J. E. Post. 1993. Managing to communicate, communicating to manage: how leading companies communicate with employees. Organization Dynamics 22: 31-43.

Zaleznik, A. 1992. Managers and leaders: are they different? Harvard Business Review (March-April): 126-135. 
Ismail \& Ahmad_Factors Affecting Effectiveness of Change Initiatives

APPENDIX 1:

QUESTIONNAIRE ITEMS, MEANS, STANDARD DEVIATIONS AND CORRELATIONS WITH COMPOSITE VARIABLE EFFECTIVENESS

Table I-1. Change Background and Strategy

\begin{tabular}{|c|c|c|c|c|}
\hline $\begin{array}{c}\text { Item } \\
\text { No. }\end{array}$ & Item Description & M & SD & $\begin{array}{c}\text { Correlation } \\
\text { with } \\
\text { Effectiveness }\end{array}$ \\
\hline $\mathrm{H} 1$ & $\begin{array}{l}\text { From the following descriptions of change } \\
\text { strategies, please tick one response which } \\
\text { best describes the changes that have taken } \\
\text { place in your organization - Fine Tuning }\end{array}$ & 0.23 & 0.17 & 0.313 \\
\hline $\mathrm{H} 2$ & $\begin{array}{l}\text { From the following descriptions of change } \\
\text { strategies, please tick one response which } \\
\text { best describes the changes that have taken } \\
\text { place in your organization - Incremental } \\
\text { Adjustment }\end{array}$ & 0.20 & 0.18 & 0.011 \\
\hline $\mathrm{H} 3$ & $\begin{array}{l}\text { From the following descriptions of change } \\
\text { strategies, please tick one response which } \\
\text { best describes the changes that have taken } \\
\text { place in your organization - Modular } \\
\text { Transformation }\end{array}$ & 0.21 & 0.21 & 0.004 \\
\hline H4 & $\begin{array}{l}\text { From the following descriptions of change } \\
\text { strategies, please tick one response which } \\
\text { best describes the changes that have taken } \\
\text { place in your organization - Corporate } \\
\text { Transformation }\end{array}$ & 0.28 & 0.21 & -0.428 \\
\hline
\end{tabular}

Note: Variables indicate proportion of respondents selecting that option - see Chapter 4 for explanation 
Table I-2. Vision

\begin{tabular}{|c|c|c|c|c|}
\hline $\begin{array}{l}\text { Item } \\
\text { No. }\end{array}$ & Item Description & $\mathbf{M}$ & SD & $\begin{array}{l}\text { Correlation } \\
\text { with } \\
\text { Effectiveness }\end{array}$ \\
\hline \multicolumn{5}{|c|}{ The introduction of the change was accompanied by: } \\
\hline I1 & $\begin{array}{l}\text { A limited number of clear and consistent themes } \\
\text { or directions for change }\end{array}$ & 3.37 & 0.30 & 0.122 \\
\hline $\mathrm{I} 2$ & $\begin{array}{l}\text { Not such an excessive number of themes and } \\
\text { directions as to cause confusion }\end{array}$ & 3.38 & 0.25 & 0.424 \\
\hline $\mathrm{I} 3$ & $\begin{array}{l}\text { A clear linkage of the change to the strategic } \\
\text { issues impacting on the organization }\end{array}$ & 3.24 & 0.34 & $0.646 * *$ \\
\hline $\mathrm{I} 4$ & $\begin{array}{l}\text { An explanation of the advantages to key internal } \\
\text { groups (employees, management, unions) }\end{array}$ & 3.47 & 0.37 & $0.709 * *$ \\
\hline I5 & $\begin{array}{l}\text { An explanation of the advantages to key } \\
\text { external groups (clients, customers, suppliers) }\end{array}$ & 3.11 & 0.45 & $0.551 * *$ \\
\hline I6 & A clear rationale for the change & 3.49 & 0.45 & $0.658 * *$ \\
\hline I7 & $\begin{array}{l}\text { A discussion on specific new ways in which } \\
\text { structure, systems and people practices } \\
\text { would change }\end{array}$ & 3.29 & 0.40 & $0.642 * *$ \\
\hline I8 & $\begin{array}{l}\text { A plan detailing the various steps of the } \\
\text { change }\end{array}$ & 3.15 & 0.45 & $0.797 * *$ \\
\hline I9 & $\begin{array}{l}\text { A clear indication of how the change would } \\
\text { impact upon your job }\end{array}$ & 3.03 & 0.53 & $0.710 * *$ \\
\hline I10 & $\begin{array}{l}\text { A description of new core values and } \\
\text { beliefs needed to make the change successful }\end{array}$ & 3.37 & 0.31 & 0.284 \\
\hline I11 & $\begin{array}{l}\text { A clear picture of how the organization } \\
\text { will look like in the future }\end{array}$ & 3.37 & 0.54 & $0.776 * *$ \\
\hline
\end{tabular}

Note: Response format: 1 = Strongly Disagree, 2 = Disagree, $3=$ Neutral, 4 = Agree, $5=$ Strongly Agree

**. Correlation is significant at the 0.01 level (2-tailed) 
Ismail \& Ahmad_Factors Affecting Effectiveness of Change Initiatives

Table 1-3. Leadership and Management Practice

\begin{tabular}{|c|c|c|c|c|}
\hline $\begin{array}{l}\text { Item } \\
\text { No. }\end{array}$ & Item Description & $\mathbf{M}$ & SD & $\begin{array}{l}\text { Correlation } \\
\text { with } \\
\text { Effectiveness }\end{array}$ \\
\hline $\mathrm{J} 1$ & $\begin{array}{l}\text { The CEO and top management created a belief that } \\
\text { the old ways were unsatisfactory }\end{array}$ & 3.33 & 0.48 & 0.223 \\
\hline $\mathrm{J} 2$ & $\begin{array}{l}\text { Once the change program commenced, there was clear } \\
\text { evidence of the CEO and top management team sharing and } \\
\text { championing a new vision for the organization }\end{array}$ & 3.33 & 0.60 & $0.722 * *$ \\
\hline $\mathrm{J} 3$ & $\begin{array}{l}\text { Considerable upheaval occurred at top management } \\
\text { levels tocreatea critical mass of support for the change }\end{array}$ & 3.13 & 0.44 & $0.694 * *$ \\
\hline $\mathrm{J} 4$ & $\begin{array}{l}\text { Management time, patience and support were given } \\
\text { to those who experienced difficulties in adjusting to } \\
\text { new ways }\end{array}$ & 2.93 & 0.43 & $0.816 * *$ \\
\hline J5 & $\begin{array}{l}\text { The CEO and senior management clearly shared a } \\
\text { common change vision and ideology }\end{array}$ & 3.37 & 0.52 & $0.580 *$ \\
\hline J6 & $\begin{array}{l}\text { From the beginning, there was a powerful guiding } \\
\text { executive coalition clearly in support of the change }\end{array}$ & 3.18 & 0.43 & $0.779 * *$ \\
\hline $\mathrm{J} 7$ & $\begin{array}{l}\text { The CEO and senior management created and } \\
\text { communicated a sense of urgency throughout the } \\
\text { organization }\end{array}$ & 3.32 & 0.34 & $0.566 *$ \\
\hline J8 & $\begin{array}{l}\text { Managers set examples by modeling appropriate } \\
\text { behaviors }\end{array}$ & 3.03 & 0.60 & $0.803 * *$ \\
\hline J9 & $\begin{array}{l}\text { Top management led the change with every word } \\
\text { and action }\end{array}$ & 3.09 & 0.64 & $0.886 * *$ \\
\hline $\mathrm{J} 10$ & $\begin{array}{l}\text { Change was continually emphasized from the top } \\
\text { so that things would not go back to the way they were }\end{array}$ & 3.31 & 0.52 & $0.782 * *$ \\
\hline $\mathrm{J} 11$ & $\begin{array}{l}\text { The CEO and senior management developed a broad } \\
\text { base of support with other individuals who first } \\
\text { acted as followers, then as helpers and finally as co- } \\
\text { owners of the change }\end{array}$ & 3.09 & 0.43 & $0.856 * *$ \\
\hline $\mathrm{J} 12$ & $\begin{array}{l}\text { Staff at all levels were given full opportunity to participate } \\
\text { in the change }\end{array}$ & 3.05 & 0.57 & $0.543 *$ \\
\hline $\mathrm{J} 13$ & $\begin{array}{l}\text { Management were pleased to receive suggestions } \\
\text { for improvement }\end{array}$ & 3.10 & 0.47 & $0.712 * *$ \\
\hline $\mathrm{J} 14$ & $\begin{array}{l}\text { Prompt feedback was given by managers to staff on } \\
\text { any suggestions made }\end{array}$ & 2.86 & 0.40 & $0.856 * *$ \\
\hline $\mathrm{J} 15$ & Management were prepared to act on these suggestions & 3.01 & 0.43 & $0.832 * *$ \\
\hline
\end{tabular}

Note $:$ Response format: 1 = Strongly Disagree, $2=$ Disagree, $3=$ Neutral, $4=$ Agree, 5 $=$ Strongly Agree

**. Correlation is significant at the 0.01 level (2-tailed)

* . Correlation is significant at the 0.05 level (2-tailed) 
Gadjah Mada International Journal of Business, January 2003, Vol. 5, No. 1

Table I-4. Resources

\begin{tabular}{|c|c|c|c|c|}
\hline $\begin{array}{l}\text { Item } \\
\text { No. }\end{array}$ & Item Description & $\mathbf{M}$ & SD & $\begin{array}{l}\text { Correlation } \\
\text { with } \\
\text { Effectiveness }\end{array}$ \\
\hline $\mathrm{K} 1$ & $\begin{array}{l}\text { Adequate financial resources were } \\
\text { allocated in support of the change }\end{array}$ & 3.24 & 0.33 & $0.602 *$ \\
\hline $\mathrm{K} 2$ & $\begin{array}{l}\text { Adequate human resources were allocated } \\
\text { in support of the change }\end{array}$ & 2.98 & 0.47 & $0.774 * *$ \\
\hline $\mathrm{K} 3$ & $\begin{array}{l}\text { Senior management were prepared to } \\
\text { devote their time to meetings, presentations, } \\
\text { communication, education and training } \\
\text { needed to support the change }\end{array}$ & 3.37 & 0.51 & $0.587 *$ \\
\hline $\mathrm{K} 4$ & $\begin{array}{l}\text { Employees received adequate and } \\
\text { appropriate training to keep up with changes } \\
\text { within the organization }\end{array}$ & 2.92 & 0.46 & $0.577 *$ \\
\hline
\end{tabular}

Note: Response format: $1=$ Strongly Disagree, $2=$ Disagree, $3=$ Neutral, $4=$ Agree, $5=$ Strongly Agree

**. Correlation is significant at the 0.01 level (2-tailed)

* . Correlation is significant at the 0.05 level (2-tailed) 
Ismail \& Ahmad_Factors Affecting Effectiveness of Change Initiatives

Table I-5. Motivation and Rewards

\begin{tabular}{|c|c|c|c|c|}
\hline $\begin{array}{l}\text { Item } \\
\text { No. }\end{array}$ & Item Description & $\mathbf{M}$ & SD & $\begin{array}{l}\text { Correlation } \\
\text { with } \\
\text { Effectiveness }\end{array}$ \\
\hline \multicolumn{5}{|c|}{ The change was supported because: } \\
\hline L1 & It provided satisfaction for a job well done & 3.06 & 0.55 & $0.880 * *$ \\
\hline $\mathrm{L} 2$ & $\begin{array}{l}\text { It provided the opportunity for new and exciting } \\
\text { challenges, enabling me to develop my skills } \\
\text { and capabilities }\end{array}$ & 3.32 & 0.52 & $0.774 * *$ \\
\hline L3 & $\begin{array}{l}\text { If people did not go along with new changes, they } \\
\text { would be penalized }\end{array}$ & 2.85 & 0.31 & 0.037 \\
\hline L4 & I got paid more as a result of the change & 2.39 & 0.47 & $0.778 * *$ \\
\hline L5 & $\begin{array}{l}\text { My own team members expected me to act in ac- } \\
\text { cordance with the new rules of the game }\end{array}$ & 3.40 & 0.36 & $0.493 *$ \\
\hline L6 & $\begin{array}{l}\text { There was little chance of advancement in the } \\
\text { organization unless we embraced the change }\end{array}$ & 3.34 & 0.32 & 0.228 \\
\hline L7 & $\begin{array}{l}\text { I played the game, but inside I am cynical about } \\
\text { the whole thing }\end{array}$ & 3.00 & 0.31 & $-0.511 *$ \\
\hline L8 & $\begin{array}{l}\text { Staff identified with managers who set examples by } \\
\text { modeling appropriate behaviors }\end{array}$ & 3.22 & 0.41 & $0.688 * *$ \\
\hline L9 & $\begin{array}{l}\text { Staff internalized the change so completely that } \\
\text { appropriate behaviors were bound to occur no } \\
\text { matter who was driving the changes }\end{array}$ & 2.85 & 0.34 & $0.931 * *$ \\
\hline L10 & We felt a sense of personal ownership of the change & 2.99 & 0.47 & $0.825 * *$ \\
\hline L11 & $\begin{array}{l}\text { People who actively support the change were } \\
\text { recognized in visible ways }\end{array}$ & 3.15 & 0.42 & $0.594 *$ \\
\hline L12 & $\begin{array}{l}\text { People who resisted the change were penalized } \\
\text { in visible ways }\end{array}$ & 2.81 & 0.36 & 0.015 \\
\hline
\end{tabular}

Note: Response format: 1 = Strongly Disagree, 2 = Disagree, $3=$ Neutral, 4 = Agree, $5=$ Strongly Agree

**. Correlation is significant at the 0.01 level (2-tailed)

* . Correlation is significant at the 0.05 level (2-tailed) 
Gadjah Mada International Journal of Business, January 2003, Vol. 5, No. 1

Table 1-6. Structuring for Change

\begin{tabular}{|c|c|c|c|c|}
\hline $\begin{array}{c}\text { Item } \\
\text { No }\end{array}$ & Item Description & M & SD & $\begin{array}{l}\text { Correlation } \\
\text { with } \\
\text { Effectiveness }\end{array}$ \\
\hline M1 & $\begin{array}{l}\text { There was clear evidence of a particular } \\
\text { person or persons driving the change }\end{array}$ & 3.58 & 0.41 & 0.392 \\
\hline M2 & $\begin{array}{l}\text { The change was coordinated from the top } \\
\text { through a steering committee or change } \\
\text { management team }\end{array}$ & 3.72 & 0.42 & 0.439 \\
\hline M3 & $\begin{array}{l}\text { A range of task forces, pilot projects and so } \\
\text { on were set up in support of the change }\end{array}$ & 3.51 & 0.50 & 0.137 \\
\hline M4 & $\begin{array}{l}\text { In each department or section, there was a } \\
\text { change "transition manager" (full or part- } \\
\text { time person specifically nominated to deal } \\
\text { with change matters) }\end{array}$ & 2.93 & 0.57 & $0.599 *$ \\
\hline M5 & $\begin{array}{l}\text { There was a network of such transition } \\
\text { managers who regularly met with } \\
\text { management to progress change related } \\
\text { issues }\end{array}$ & 3.23 & 0.46 & 0.368 \\
\hline M6 & $\begin{array}{l}\text { Feedback mechanisms were developed to } \\
\text { provide transition managers with } \\
\text { information on problems that were being } \\
\text { experienced and on solutions that were } \\
\text { devised }\end{array}$ & 3.06 & 0.45 & $0.673 * *$ \\
\hline M7 & $\begin{array}{l}\text { Throughout the change, there was always } \\
\text { a distinct network of people at all levels } \\
\text { from whom I could get answers/action }\end{array}$ & 2.91 & 0.51 & $0.725 * *$ \\
\hline M8 & $\begin{array}{l}\text { I could clearly identify a "change } \\
\text { management structure" (and } \\
\text { communication network) as distinct from } \\
\text { the normal hierarchical structure }\end{array}$ & 2.99 & 0.52 & $0.629 * *$ \\
\hline M9 & $\begin{array}{l}\text { The structural arrangements devised for } \\
\text { managing change greatly enhanced } \\
\text { communication allowing for rapid } \\
\text { responses to all contingencies }\end{array}$ & 2.94 & 0.47 & $0.796 * *$ \\
\hline
\end{tabular}

Note: Response format: $1=$ Strongly Disagree, $2=$ Disagree, $3=$ Neutral, $4=$ Agree, $5=$ Strongly Agree

**. Correlation is significant at the 0.01 level (2-tailed)

*. Correlation is significant at the 0.05 level (2-tailed) 
Ismail \& Ahmad_Factors Affecting Effectiveness of Change Initiatives

Table I-7. Communication

\begin{tabular}{|c|c|c|c|c|}
\hline $\begin{array}{l}\text { Item } \\
\text { No. }\end{array}$ & Item Description & $\mathbf{M}$ & SD & $\begin{array}{l}\text { Correlation } \\
\text { with } \\
\text { Effectiveness }\end{array}$ \\
\hline \multicolumn{5}{|c|}{ Perceived extent to which the following approaches were used to facilitate the change: } \\
\hline N1 & $\begin{array}{l}\text { Regular messages related to the change on } \\
\text { bulletin boards and/or other public forums }\end{array}$ & 3.33 & 0.57 & $0.558 *$ \\
\hline $\mathrm{N} 2$ & $\begin{array}{l}\text { Special words or symbols that emphasize change } \\
\text { - e.g. teamwork, quality, multi-skilling, process } \\
\text { re-engineering, best practices, benchmarking }\end{array}$ & 3.50 & 0.44 & 0.363 \\
\hline N3 & $\begin{array}{l}\text { Special and regular communication on the } \\
\text { change such as a change newsletter }\end{array}$ & 3.20 & 0.61 & 0.385 \\
\hline N4 & $\begin{array}{l}\text { Meetings devoted specifically to communicating } \\
\text { change issues }\end{array}$ & 3.32 & 0.34 & 0.462 \\
\hline N5 & $\begin{array}{l}\text { Recognition and reward for those who support } \\
\text { the change }\end{array}$ & 2.90 & 0.47 & $0.806 * *$ \\
\hline N6 & $\begin{array}{l}\text { Managers visibly support the change through } \\
\text { word and action }\end{array}$ & 3.20 & 0.49 & $0.910 * *$ \\
\hline \multicolumn{5}{|c|}{$\begin{array}{l}\text { Perceived effectiveness to which the following approaches were used to facilitate the } \\
\text { change: }\end{array}$} \\
\hline N7 & $\begin{array}{l}\text { Regular messages related to the change on } \\
\text { bulletin boards and/or other public forums }\end{array}$ & 3.25 & 0.56 & $0.600 *$ \\
\hline N8 & $\begin{array}{l}\text { Special words or symbols that emphasize change } \\
\text { - e.g. teamwork, quality, multi-skilling, process } \\
\text { re-engineering, best practices, benchmarking }\end{array}$ & 3.38 & 0.45 & $0.660 * *$ \\
\hline N9 & $\begin{array}{l}\text { Special and regular communication on the } \\
\text { change such as a change newsletter }\end{array}$ & 3.24 & 0.52 & $0.593 *$ \\
\hline N10 & $\begin{array}{l}\text { Meetings devoted specifically to communicating } \\
\text { change issues }\end{array}$ & 3.35 & 0.46 & $0.721 * *$ \\
\hline N11 & $\begin{array}{l}\text { Recognition and reward for those who support } \\
\text { the change }\end{array}$ & 3.08 & 0.37 & $0.803 * *$ \\
\hline N12 & $\begin{array}{l}\text { Managers visibly support the change } \\
\text { through word and action }\end{array}$ & 3.31 & 0.43 & $0.745 * *$ \\
\hline
\end{tabular}

Note: Response format: $1=$ Strongly Disagree, $2=$ Disagree, $3=$ Neutral, $4=$ Agree, $5=$ Strongly Agree

**. Correlation is significant at the 0.01 level (2-tailed)

* . Correlation is significant at the 0.05 level (2-tailed) 
Gadjah Mada International Journal of Business, January 2003, Vol. 5, No. 1

Table I-8. Change Outcomes - Perceived Effectiveness of the Change

\begin{tabular}{|c|c|c|c|c|}
\hline $\begin{array}{l}\text { Item } \\
\text { No }\end{array}$ & Item Description & $\mathbf{M}$ & SD & $\begin{array}{l}\text { Correlation } \\
\quad \text { with } \\
\text { Effectiveness }\end{array}$ \\
\hline \multicolumn{5}{|c|}{ The change resulted in: } \\
\hline $\mathrm{O} 1$ & Improved products or services & 3.46 & 0.63 & $0.979^{* *}$ \\
\hline $\mathrm{O} 2$ & Measurably higher productivity & 3.32 & 0.58 & $0.953^{* *}$ \\
\hline $\mathrm{O} 3$ & Improved services to customers and clients & 3.53 & 0.52 & $0.964 * *$ \\
\hline $\mathrm{O} 4$ & $\begin{array}{l}\text { Measured improvements in goal-oriented } \\
\text { criteria, such as revenues, growth, }\end{array}$ & 3.41 & 0.54 & $0.943^{* * *}$ \\
\hline O5 & Improved efficiency & & & \\
\hline O6 & $\begin{array}{l}\text { Greater ability to compete in the market } \\
\text { place }\end{array}$ & 3.37 & 0.57 & $0.933^{* *}$ \\
\hline $\mathrm{O} 7$ & $\begin{array}{l}\text { An overriding culture of quality and } \\
\text { excellence }\end{array}$ & 3.22 & 0.59 & $0.981 * *$ \\
\hline O8 & $\begin{array}{l}\text { A sense of awareness, belonging and } \\
\text { feeling part of the team/organization }\end{array}$ & 3.20 & 0.57 & $0.942^{* *}$ \\
\hline O9 & $\begin{array}{l}\text { A greater sense of cohesion and integration } \\
\text { in the organization }\end{array}$ & 3.11 & 0.57 & $0.941 * *$ \\
\hline $\mathrm{O} 10$ & $\begin{array}{l}\text { Greater long-term health of the } \\
\text { organization }\end{array}$ & 3.46 & 0.63 & $0.942 * *$ \\
\hline
\end{tabular}

Note $:$ Response format: 1 = Strongly Disagree, 2 = Disagree, $3=$ Neutral, 4 = Agree, $5=$ Strongly Agree

**. Correlation is significant at the 0.01 level (2-tailed) 